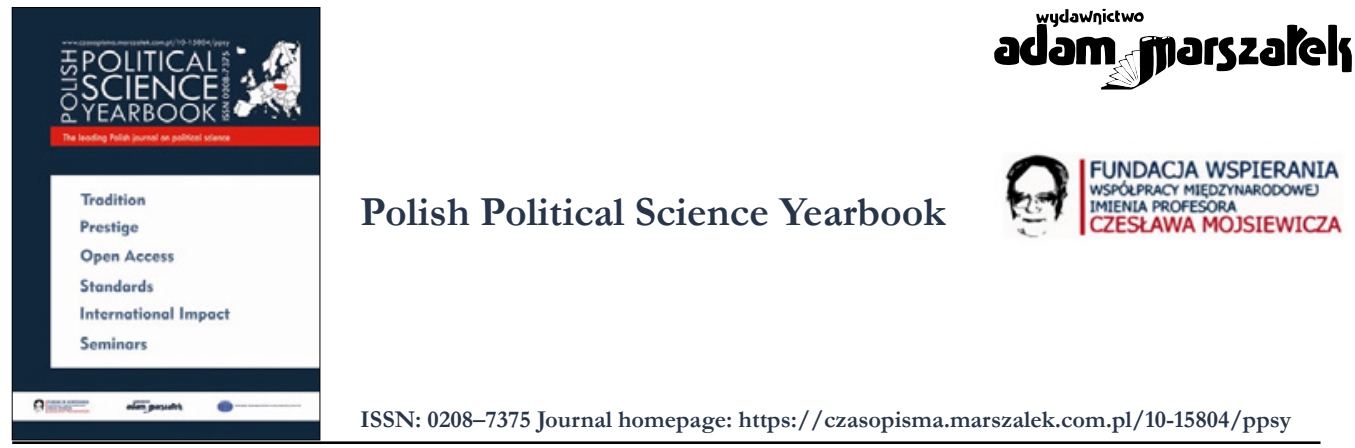

\title{
Cultural Security in Shaping the Generation of Civilizational Advancement Within the Universalization of Cultural Transformations. Based on Research Conducted in Samoa
}

\section{Mirosława Jaworowska}

ORCID: 0000-0002-3870-9336

To cite this article please include the following information:

- Journal title: Polish Political Science Yearbook

- Volume number: 50

- Year of publication: 2021

- Published ahead-of-print

Example styles:

[APA Style]: Jaworowska, M. (2021). Cultural Security in Shaping the Generation of Civilizational Advancement Within the Universalization of Cultural Transformations. Based on Research Conducted in Samoa. Polish Political Science Yearbook, 50(4), pages. https://doi. org/10.15804/ppsy202156

[Chicago Style]: Mirosława Jaworowska, "Cultural Security in Shaping the Generation of Civilizational Advancement Within the Universalization of Cultural Transformations. Based on Research Conducted in Samoa" Polish Political Science Yearbook 50, no. [4] (2021).

To link to this article: https://doi.org/10.15804/ppsy202156

Published ahead-of-print

曲 Final submission: 28 November 2021

Published online: 17 December 2021

Printed issue: 2021

Submit your article to PPSY 


\title{
Cultural Security in Shaping the Generation of Civilizational Advancement Within the Universalization of Cultural Transformations. Based on Research Conducted in Samoa
}

\begin{abstract}
The Author has demonstrated that Samoan youth is not indifferent to cultural universals, despite attempting to co-create them in the course of a multi-cultural dialogue and globalization processes. The study was founded on research results conducted through local observations and a questionnaire distributed among students of the Faculty of Education at the National University of Samoa in Apia. The research aimed to learn about the opinions, aspirations, attitudes, and value systems of Samoan students as they represent the educated elite of the 21st-century generation. The interviewed approve of contemporary civilizational novelties, as long as those do not harm the traditional culture. The socialization process in the Samoan youth has been occurring on a borderland between upbringing, traditional family-tribal, and the modern state-citizen education in schools and social life. Family and traditional customs are still vivid despite being more open to contemporary civilization and state developments. Although cautious towards novelties that might threaten the Samoan culture, these attitudes may be assessed as a reformatory. Based on the results obtained in Samoa, it is justifiable to state that the process of cultural transformation universalization has been occurring there in many areas of reality.
\end{abstract}

Keywords: culture clash, culture of security, emancipation generation, generation of civilizational advancement, system transformation, cultural transformation, value system, universalization

\section{Introduction}

The culture of security constitutes a feature of both individuals and social groups.

Sociological issues within the broadly understood security sciences have not yet been sufficiently explored nor defined. As a fundamental value in human needs, security is doubt- 
lessly a multifaceted phenomenon: existential, ontological, epistemological, and cultural. Thus, a unified definition of security is very difficult, perhaps even unfeasible at present. Security is commonly understood as an objective state and individual or social sense, which guarantees durability and stability of freedom from existential and moral threats. Many definitions of security are inclined towards such direction. Academic coursebook Theoretical and methodological fundamentals of security (Ścibiorek \& Zamiara, 2016, p. 8) provides the following definition: „(..) security is a state granting a sense of confidence and a guarantee of maintaining it. It implies an acceptable level of risk of losing something particularly dear for the individual: life, health, work, respect, feelings, tangible and intangible assets”. According to the „Introduction to the methodology of security research” (Jemioło \& Dawidczak, 2008, p. 7; Marszałek-Kawa, 2011), the subject of security theories research is a phenomenon of threats deriving from people's environment, as well as possible undertakings aimed at granting them security. These opinions and wording do not indicate, however, two significant attributes of all security phenomena, which:

1. are in a certain state of duration, range in time and space, in the process of constant shaping and changing, which may be described as dialectics of the fact of security

2. being dynamic and dialectic facts, they always constitute a risk of materializing the threat, protection or defense of threatened object - which can be called a process of insuring (Jaworowska, 2019, pp. 7-8).

A static definition of a behavior system enabling survival requires a dynamic approach to the problem of the culture of security perceived as a social fact and process. The subject of research on the sense of security of a given community is the dynamics and dialectics of behaviors and the process of forming the cultural sense of security as a risk of trust towards guarantees of successful survival and development.

The bedrock of the security culture is a value system - a starting point for norms that shape the aspirations, behaviors, attitudes, actions, and interactions of people and social groups in building common security. Pro-social ethos is defined by knowledge and way of thinking about security values specific for each person. It defines the sense of security and common practices and forms of its realization (Jaworowska, 2019, p. 59).

The culture of security in a state's functioning includes providing for the society's cultural security, understood as an ability to preserve the cultural identity, cultural goods, and national culture heritage resources while remaining widely and rationally open to a global culture, developing participation and cultural creativity of all citizens. Thus, the security culture in the standardization of the points of contact and exchange with other cultures becomes a significant issue for people's participation in worldwide cultures.

The concepts within the universal culture compete with concepts in the global culture. They are primarily founded on the universalization of cultural application of technical and IT civilization and the attempts to unify social and political relations and actions, such as unions or confederations of states. 
Neither economic, technical, social-cultural, nor political globalization can unify the axionormative systems, beliefs, or customs; at least at their present level of progression and functional features. Likewise, the concept of global culture is rather shallow and precipitous. Globalization of culture is a long-lasting competition between values: religious, social, legal, and commercial/market-related.

\section{The conditions of early youth socialization of the interviewed Samoan students}

The present study derives from the author's three expeditions to Polynesia in the early 2000s and is based on the analyses of the research results. The research was conducted through a questionnaire among students of the Faculty of Education at the National University of Samoa in Apia - the capital of the Independent State of Samoa. This research aimed to learn about the opinions, aspirations, attitudes, identity, and value systems of the Samoan students as they represent the educated elite of the young generation of this Polynesian country. It has been assumed that students of pedagogics, descending from various islands of the Samoa archipelago, would represent the young generation's state of mind and knowledge. In the research, 95 exhaustive responses were obtained to the questionnaire (elaborated in English), which contained 14 open questions and 12 semi-open questions. The interviewed group consisted of 75 women and 20 men, in line with this faculty's predominantly female enrollment. The interviewed persons belonged to the following age groups: 63 persons 21-30 years old, 14 persons under 20 years of age, 14 persons - 31-40 years old, and four persons over 40 years of age. The differentiation of ages results from the fact that only $20 \%$ of respondents were just studying - others simultaneously work as teachers in primary or vocational schools. The respondents know more than just their own country. Sixty-one persons reported a few months' long journeys, mainly to New Zealand or Australia, while some were as far as Thailand, Korea, or Japan. Thirty-one persons admitted to using a computer and the Internet daily. All students can use the Internet at their university.

A hypothesis was formed that Samoan youth's socialization has been occurring on a borderland between traditional culture, family-tribal and contemporary culture, and state-citizen education in schools and social life. It was assumed that family and traditional customs are still vivid and influential, although not entirely closed to contemporary civilization and state developments. The youth's aspirations are focused on obtaining the education and profession needed by their country. Such aspirations are of emancipative character. The attitudes may be assessed as a reformatory, although cautious towards novelties that might threaten the valuable elements of the Samoan culture.

The young generation of Samoa, represented by the interviewed NUS students, in their primary socialization within families, had learned and interiorized norms and values of the Polynesian/Samoan traditional culture. These values were inculcated in them in childhood and early youth spent in the rural areas, in families and communities formed in times of 
clan-tribal domination of local structures, before the Samoan state came forth. Family, clan, respect for the elders, tribal leaders, etc. - have constituted tangible expressions of power, care, security, imposing norms of behavior and its evaluation, generalized and imprinted for life. In this life learning process, new elements and rules would appear, such as the state, police, school, medicine, radio, television. However, these elements did not blend well with the village environment and tradition.

No sooner than in the course of secondary socialization of the youth, adolescence or adulthood age (after 30) at school, among peers, while traveling, feeling a citizen of the independent state of Samoa and enjoying other worldwide cultures, did the imprinting of norms and values of contemporary global culture take place, as well as their merging or replacing norms and values of the primal socialization. The process was relatively slow, uneasy, and contemplative for the benefit of a young person's mentality.

Perhaps the above attempt to outline a personal clash of cultures might appear simplified, but it needs to be simplified to some extent. It is impossible to describe in detail individual processes of developing own identities. Therefore, more general models/patterns must be applied.

Where did the interviewed students spend their childhood and early youth? When asked, "Were you born and raised in Samoa”, eighty-one persons answered „yes”, four persons „no", and ten persons did not provide an answer. Thus, $85,3 \%$ of the interviewed students are native-born Samoans. A further open question followed: „If you were born and raised in Samoa, whereabouts was it?". Thirty-one persons did not answer, but the remaining over sixty answers were extensive, often expressive in emphasizing being a native-born Samoan and mentioning the name of villages.

Strong roots in the place of birth, mainly rural areas, and in homeland yielded a question „Have some elements of tribal-traditional culture been integrated with the youth's life experience /If Yes - describe shortly what areas of life this applies to?". This open question resulted in a flurry of replies which can be divided into an outright ,yes", following by a „yes but with new changes in culture”, and finally an outright "no". A direct „yes" was dominant and applied to about $50 \%$ of such answers, extensively quoted here: in every single stage of our lives as Samoans, we follow our ancestors' paths; youth's life has integrated with culture, thus a need of respect and honesty, and obeying parents in whatever they command to do; relationships with people must be maintained, as well as keeping a polite attitude and good behavior like real Samoan; the behavior of the youth is Samoan's traditional culture, to teach them how to respect others; looking after kids and helping parents in their role in the community; the maintaining of the culture in terms of respecting the older people and brothers to their sisters; living with relatives in a community; church within the villages; sharing faith within the family; it was present in our own families in childhood; I perform the duties of a Samoan woman. 


\section{Contemporary value system of the interviewed students}

The results are of great interest. They must be confronted with the scale of significance of each value, specific for both traditional and modern culture, and looked at their rational evaluations. Thus, a complex ranking question was elaborated, inquiring about the first-, second-, and third-rank of priority for sixteen selected values.

Which values were considered the first rank by the interviewed students? Four of them were predominant: family ( 67 persons), respect for elders ( 63 persons), responsibility (59 persons), and work (52 persons). The traditional culture's values are in the lead (family, respect for elders). They are followed by: gratitude (49 persons), individuality (47 persons), punctuality ( 46 persons), caring for the environment (46 persons), respect for the youth (45 persons), paternity ( 41 persons), and society ( 40 persons). The third place goes to money (39 persons), modesty (37 persons), maternity (33 persons). The last place in the ranking was assigned to ,Being first in a competition' (27 persons).

Such a hierarchy of the most important values, led by family and respect for elders, clearly emphasizes a traditional mental framework.

Ranking money and being first at the very bottom of this hierarchy might imply a certain distance toward important values of the liberal-modern Euro-American civilization. However, do the results of ranking values also reflect some signs of modern values canon infiltrating into the minds and mentalities of the Samoan students through traditional habitual assessment?

The results presented above supported a hypothesis that axionormative order in the interviewed group is currently transforming from a tribal formation to a state formation and is being shaped by merging the traditional Polynesian values with global civilization values, mass, and popular culture. Prioritizing particular values depended not only on the respondent's personal preference but also thinking on behalf of "your family", as the question implied. Thus, to some extent, the results can be applied to the majority of the Samoan society as an overture to the acculturation process.

\section{3. cultural transformation as a foundation for students' socialization}

It is a long-term evolutionary transformation, and although its expected results might lead to changing the cultural formation of the country, in that respect, it will be revolutionary but non-violent.

„An examination of Samoan society and its post-colonial history provides extraordinary evidence of that appropriating dynamic which enables it to absorb a wide variety of colonizing influences in virtually all areas of life. The social structure, law, religion, stories, and performances all reveal a society able to adapt various cultural practices with resilience and flexibility. Partly because of the strength of its structures but also because of the protean 
nature of its social dynamism, the force of imperial discourse was absorbed with remarkable adaptability into many aspects of Samoan life" (Kruse, 2011, p. 22).

Since gaining independence in 1962, the nation has faced a dilemma of „balancing fa'a Samoa - Samoan customs and traditions - and Western, rational-legal' systems of authority. (..) Western Samoa's present legislative structure was adopted in 1962, providing two systems of the legal resort to Samoans. When individuals, , aiga (descent groups), $n u^{\prime} u$ (villages), itumalo (districts), and the national government take disputes to court, they may invoke either of these sources of authority to legitimize their actions and claims. The problem is particularly severe for the Land and Titles Court, a body legally constituted to deal with matters of traditional significance" (Meleisea, 1987, p. 11).

A similar dilemma has been observed in the cultural aspect. Currently, in the examined environment, two canons of traditional values are present: emotional and reflective dominance of family value as a continuation of its significance in the traditional family line and the state - perceived as a continuation of attachment to the tribal homeland. There is also a seed of a Samoan national identity consciousness, perceived as a continuation of sensing homeland. This awareness is purposefully stimulated by education and propaganda led by an independent state, such as in the name of the local university - National University of Samoa - and its curriculum.

The students live in and identify themselves with a culture undergoing a cultural clash: the values and products of the traditional Samoan culture meet the values and products of modern popular culture, influenced mostly by the neighboring Australian-New Zealand impact, mass media, and Internet. This clash of cultures is not of a confrontational, sharp conflict character. Nonetheless, it raises certain concerns and controversies and requires a reflective and emotional choice, which is not simple, as documented in the students' statements.

At this point, I would like to refer to the Samoan youth studies conducted by Margaret Mead in the $20^{\text {th }}$ century. Her typology of the succession of generations and the overall prognosis of the young Samoan generation forming prefigurative culture have been adopted herein, leading to my hypothesis of this process being currently materialized. The interviewed NUS students meet the criteria of a prefigurative culture generation. They are open to the world without forgetting the tradition and native place. They look into the future and shape it nowadays in a human, tolerant way, referring to many noble moral values of their ancestors (respect, honesty, responsibility, loyalty, gratitude, modesty, sharing with others, hospitality, etc.). They adopt a dignified, responsible, and selectively modern innovational value system and lifestyle.

The obtained data denoted their openness to the world, other people, and other cultures while lacking a traditional sectionalism. 


\section{Elements of universalization in the cultural transformations}

The research results on Samoa have led to forming a hypothesis that significant elements of culture transformations' universalization have started to occur in the researched area. It should be concluded that noting and highlighting this issue might be of great importance for research work and theories regarding cultural changes in various countries and cultures, including Eurasia, European Union, or any American, African, or Asian unions, all of them heading toward cooperation and cultural exchange.

What is understood by the elements of universalization in the cultural transformations"? The concept implies a process, shared within a specific environment, of similarizing cultural patterns and values due to their continuance or synthesis in given conditions (only selected elements of this complex process are considered in this study). In Samoa, this process can be reflected in the following summarized form:

Table 1. Selected elements of universalization of the cultural changes

\begin{tabular}{|c|c|c|c|c|}
\hline & Value & Traditional & Modern & Towards synthesis of \\
\hline 1. & Religion & Mythology & Doctrine & eclecticism \\
\hline 2. & Authority & $\begin{array}{l}\text { chief, tribe, tribal } \\
\text { council }\end{array}$ & Family and law & democracy and chief \\
\hline 3. & Political culture & Tribe and clan & Family and school & $\begin{array}{l}\text { political-state transforma- } \\
\text { tion }\end{array}$ \\
\hline 4. & Public rights & Male domination & Gender equalization & equalities \\
\hline 5. & Attitude towards state & Tribal-ancestral & family-state & homeland \\
\hline 6. & Family & Ancestral & Personal & identity \\
\hline 7. & Socialization & Natural-ancestral & School-family & choices \\
\hline 8. & Generations & Cult of elders & Partnership & dialogue \\
\hline 9. & Value system & Gods and ancestors & Family and good & Knowledge and my ideas \\
\hline 10. & World & Sailing to the islands & Air connections & Men of the world \\
\hline 11. & Customs & $\begin{array}{l}\text { Different based on } \\
\text { gender }\end{array}$ & Similar for genders & Individuality \\
\hline 12. & Art & Cultural-mythical & Pop-culture & Restoration of tradition \\
\hline
\end{tabular}

Source: own research.

The Polynesian religious mythology observed an abundance of gods and their influence on the creation of the world and humankind."The Samoans believed in a soul or disembodied spirit, which they called the angānga (..). The reduplicated angānga is used to designate the soul as distinct from the body, which at death was supposed to go away from the body and proceed to the hadean regions under the ocean, which they called Pulotu. (..) At one time, it was supposed that Samoa was destitute of any kind of religion, and by some of the early visitors, the people were called the "godless Samoans". On closer acquaintance with 
them, however, it was discovered that they lived under the influence of a host of imaginary deities, claiming similar beliefs and corresponding practices (Turner, 1989, pp. 16-17).

In the light of conducted research, presently, this mythology and worship of gods seem to have transformed into legends and are being replaced by the common Christian beliefs (mostly Evangelic and Catholic). Religious evolution in Samoa is likely to be heading towards citizens' individual choices and eclecticism. One of the striking views at Samoa was the large variety and number of places of worship. Compared to Melanesia and Micronesia, a very characteristic feature of Polynesia was their highly developed social organization of tribes, which included independent states ruled by kings and chiefs, along with tribe councils or advisors on religious ceremonies. The authority was shared by the king, chief, tribe, and tribal council. However, when asked who is the most important person in Samoa and why, the traditional authorities such as tribal leaders, the elders, or tribal councils were mentioned only sporadically. The predominant answer was: family, father, mother, government, prime minister. The typical justifications included: mother, as she is the person solving problems in our family; prime minister as he has the power to create institutions working for our benefit in the future as well as implementing actions which protect our way of life, he is a decisionmaker who improves the economy, education and international affairs of our country. That brings us to a hypothesis of an increasing tendency to shape and disseminate a democratic social statehood, with a recognized leader's authority (chief-king, president, prime minister), which would be an interesting merge of traditional authority of the king with a social democracy authority. Liberal democracy would be unacceptable for the heirs of a strong belief that the primacy of tribe (i.e., community over the individual) is unquestionable. Thus, the interviewed group would not accept the dominance of individual rights while they are keen on being members of a state community. When asked,"Do you consider yourself a citizen in the full meaning of this word?" Eighty percent of the respondents confirmed that they strongly feel so and are fond of living in this country. The citizens' community slowly replaces the tribal community, but a modern "chief" is indispensable in such a structure.

In the middle of the $20^{\text {th }}$ century, Margaret Mead noted the taboo rules on Samoa regarding relationships between different genders and different ages: "Relatives of different gender are respecting the rigid rules of ceremonies in all mutual contacts" (Mead, 1986, p. 51).

Nowadays, close to a century later, a process of advanced equalization of interactions and relationships between persons of different gender could be observed in Samoa. When asked whether men and women enjoy equal rights in public life, $42 \%$ of the respondents answered 'yes', over $27 \%$ - 'no' and close to $14 \%$ - 'not always'. When asked about ways of concluding marriages, over $45 \%$ replied "in a natural way, by a free selection of partners", $22 \%$ "according to common religion/church" and less than 17\% "by parents' arrangements and recommendations". Doubtlessly, the rising tendency of this process is heading towards full gender equality.

The attitude towards homeland depends largely on the person's sense of space and scale of comparison to other lands. It meant having a certain image of the clan's or tribe's land 
in the traditional culture. It was the place on earth. The ocean and starry sky were mythical spaces. Nowadays, the foundation of being is bound to family and personal ownership. The country, organized into a state, is 'co-owned' by citizens. The state guarantees such a right to personal property. As research shows, this awareness is gradually becoming more common and strengthened, leading to individualized attitudes towards own country and its environment, with a possibility of wandering and comparing impressions with the whole world. On the other hand, the former tribal-nature attachment to the "place of life and death" left a strong mark in the form of a subconscious fascination with nature and the "spiritual" climate of the homeland. When asked, "what does living in Samoa mean to you", an astonishing $80 \%$ of the respondents pointed out "beloved places, scenery, scents" next to "family, friends". Likewise, when asked what they would lose by leaving the country forever, a frequent statement was: beauty, landscape, nature, an atmosphere of the homeland. The awareness of the traditional "tribal ground" is being replaced by "homeland".

Presently, a Samoan family is more integrated. It is not as much dependent on the clan-tribal organization. It was observed throughout the research that family, side by side with the state, is perceived as a counselor and guardian of the order and discipline, i.e., the first rank value in the axionormative system of the interviewed group. Therefore, family is becoming a personal, close, indispensable being. It gradually becomes a component of personal identity, of the own "self".

The generational attitude towards cultural transformation is visible among the Samoan students. In the past, in the traditional tribal systems, the significant role of the elders derived from the fact that only age could provide the knowledge, experience, and skills that could be passed on to the youth or advise leaders and shamans. The wisdom of the elders became a taboo, a form of an act from gods.

Presently, the respect and support toward older people show a more generationalemotional character, however with the participation of traditions (without the cult of wisdom) stemming from the knowledge and digital information. The majority of Samoan students use computers and the Internet. When choosing the country's most important authorities, they have ranked them based on wisdom, experience, acting for the common good. Age does not seem to be a crucial criterion of choice. The youth are often keener to introduce novelties into family and country life; they are more curious about learning modern theories, attitudes, and discoveries. Intergenerational relations gradually become based on partnership, knowledge, competences, and skills at work and public duties, heading toward a rational intergenerational dialogue.

Employing the analyses, the author attempted to indicate specific elements of the universalization of cultural phenomena and transformation processes in Samoa. One of the interview questions was elaborated in the form of a table, allowing the respondents to choose among sixteen values that they consider first, the second, and the third rank of importance. We have obtained some solid answers, enabling a proper targeting of the respondents' value system and ascertaining a significant consistency in the first rank choices. 
The students were unanimous in their choice of universal cultural values, important in a tribal and state-society: family, respect for elders, caring for the natural environment. The students are adapting the commonly chosen respect for elders to a contemporary custom; so is the higher rank of respect for the youth. Generally, a tendency that makes social values universal has been distinctly observed. Personal values, in moral philosophy referred to as virtues, also perform a social function. They are, however, commonly applied to units that form a group - responsible, grateful or punctual - and hence create a collective, social virtue. Responsibility, diligence, and gratitude were the dominant virtues chosen by respondents. They are also functionally nearest (and practically combined) to the predominant values chosen by respondents: a responsible, hardworking family, gratitude for older people, maternal modesty. However, such a choice of personal virtues suggests that in the $21^{\text {st }}$ century, the descendants of the traditional culture generation are, to some extent, modernizing and universalizing the axionormative system.

Concluding the above analysis, the author would like to emphasize that it is just an initial outline of a complex issue, requiring systematic development and further insight. The basic category of the universalization of cultural transformation itself requires further discourse and more precise definitions. It would be recommended to gauge the level of cultural changes occurring in Samoa, perhaps by using G.P. Murdock's theory on cultural transformation.

The first stage of such cultural transformation is defined by Murdock as an initiation of a process of innovation and forming habits by individuals, followed by acceptance and their gradual acquiring by the whole society. Murdock states that the second stage is already a full social acceptance, occurring after approval of the innovation as the initiating group's feature, followed by practical implementation and complete dissemination within a given society. The third stage consists of verifying the innovation's functionality within the society so that the innovation, after some adaptations, can be integrated with the cultural entity of the environment (Murdock, 1960). Clearly, Samoa is still facing some stages of its cultural transformation.

\section{Conclusion}

Human sciences should focus on multi-aspect intellectual proposals for the world's future. I have repeatedly touched upon these issues when analyzing the research results, as the obtained material exhibits a synthesis of cultural values in shaping $21^{\text {st }}$-century youth's personalities and lifestyles. Online utterances will play an increasing role in such analyses, particularly when discussing the creative role of the young generation in a multi-cultural dialogue, leading eventually to global dissemination and acceptance of universal values. The researchers' task is to co-create such a historical transformation and thus lead to a better understanding of the youth's role in the historical process structure. As mentioned before, young people perceive familiar universal values as their own while not abandoning or neglecting the culture of their inheritance, so-called cultural roots. They appreciate significant 
universal elements in those roots, which their grandparents (and even parents) could not distinguish and appraise, for they had lived in a value circle of one culture, quite hermetic to other values, in an environment of the restricted flow of multi-cultural information. It is the first generation that may enjoy such all-round multi-cultural participation on a global scale and opportunities to choose the content and form of such participation via the Internet and other electronic communication of global reach.

Based on the Samoan research, the term "generation of civilizational advancement" seems to be the crux in forming aspirations, value systems, lifestyles, and aims of the current young generation globally, with various intensities (depending on the country). In such a process of advancement (uneasy and risky in many areas), consumption and advertised consumptionism play their part, sometimes positive, other times negative.

Based on the results of research conducted using a questionnaire and observations on Samoa, the following thesis may be formed: the universalization of cultural transformations is presently occurring in many areas of reality.

It has been proven that a religious belief transforms from a mythical state into Christianity and reveals a tendency towards multi-religiousness. The authority model is transforming into a state-family one (law and family), showing a tendency toward further democratization. A parochial political culture (clan and tribe) transmutes into a succumb culture (family and school), with a tendency toward political transformation towards participatory culture. Male dominance in public and tribal life transmutes equality before the law. The clan-tribal approach to life territory has been transforming into a family-state one, forming a homeland patriotism. A family, immersed in a clan, becomes autonomous, a personal manifestation of identity. The clan socialization of youth demonstrates, in fact, a more school-family character of own choice. Regarding intergenerational relations, the cult of elders gives way to partnerships, heading toward generational dialogue, although the respect for older people is very high.

The interviewed group consists mainly of students of pedagogics - does it make them a better representation of the whole young population of Samoa than students from other faculties would be? I think it does, one of the reasons being the answers to the question, "Where were you born" - frequently commented as "in a village", "away from Apia", "on a different island". Hence, those young Samoans seem to represent all environment ranges, in terms of their childhood and youth upbringing, from the archipelago islands to the capital city of Apia - most of those young people did not come from a large city (Apia) or other cities. Of course, we cannot treat the interviewed population as a statistical sample of all young Samoans or university students, but we can consider it a purposefully chosen cultural sample of the young Samoan generation.

Some may discredit such a purposeful sample since almost eighty percent of the interviewed were female students. However, that is the gender structure at the NUS faculty of education. In my opinion, such female domination in the purposeful "sample of culture" can be evaluated positively in the qualitative studies, as the research indicates that this gender 
experiences the clash of modern versus traditional culture the most, which is the ultimate goal of our work: to qualitatively present, examine and interpret the essence of these cultural clashes. The fact that female students dominate in this group makes the task easier.

In line with the project, the Samoan clash of cultures was examined using a culturological analysis of three aspects: political culture (state-society integration process), socialization of the young generation (tradition-modernity acculturation process), and finally, youth emancipation (the youth-state process of becoming a citizen). The study is not multisided in terms of documentation, but it does cover elements of the processes and thus is sufficient to formulate hypotheses for further research. Such research method has been validated in scientific practices, among others by A. Schutze.

In the light of the respondents' opinions, the young generation's socialization occurs under the influence of acculturation processes, i.e., clashing traditional culture with modern culture. According to the interviewed students, extreme revolutionary frames of mind do not occur within the Samoan society. We can distinguish, however, reformatory, conformist and traditionalistic attitudes.

Taking into consideration the analyzed aspects of transformations taking place in Samoa, it can be stated that the Samoan society has been evolving into a $21^{\text {st }}$-century state organization - sovereign and acquiring its own civilizational-cultural shape. This process has been dominated by a clash of cultures: traditional Samoan and contemporary, global mass culture. The process has been largely influenced by the evolution of views, aspirations, and attitudes of the young generation, particularly those who are obtaining higher education and, in the nearest future, will be shaping the intellectual and cultural environment of the country. A significant role in reaching such goals will be assigned to the teachers and students aspiring to become teachers - i.e., the interviewed group.

The Samoan research aimed to obtain data and analyze social transformations on the verge of the $21^{\text {st }}$ century. This manuscript constitutes a partial realization of such a goal, as it presents the analysis concluded in the sociological and anthropological categories, utilizing the principles of theory on social transformation. It has been one of the most crucial issues in sociology since it became a science. In formulating theses and analyses deriving from our collected research material, I have proposed introducing a few conceptual categories to enable an accurate description of the studied phenomena and processes. These categories include a term of the islanders' system of values, aspirations, attitudes, and lifestyles, inspired by the existential significance of the maritime environment, nature, the psychological and economic role of the ocean in shaping the islanders' life, personalities, strength, and identity. The islanders' identity contributes to a strong sense of community, shared direction of life, and defining own citizenship through islander family and community. The cultural and educational policy of the Samoan state appreciates a modern, reformatory value system and attitudes, which in a conscious, balanced way adapt values from other cultures without harming the traditions. The results of research, which were difficult to be obtained, may prove their reflexive importance for the contemporary people and raise the interest of Oceania's 
Islander communities. The findings might also be useful for international security analysts, politicians, and sociologists.

\section{References}

Giddens, A. (2001). Nowoczesność i tożsamość. PWN.

Institute of Pacific Studies. (1984). The Constitution of the Independent State of Western Samoa. Pacific Constitutions, vol. 1. Suva.

Jaworowska, M. (2017). Bezpieczne perspektywy Samoa i Niue. Wydawnictwo Adam Marszałek.

Jaworowska, M. (2010). Świat kultury Maori w Nowej Zelandii. Prodruk Oficyna PoligraficznoWydawnicza.

Jaworowska, M., Gołębiowski, B. (2013). Przyszłość jest teraz. Wartości badań Margaret Mead nad dojrzewaniem młodych pokoleń Polinezji i USA dla wspótczesności. Wydawnictwo Adam Marszałek. Jaworowska, M. (2018). Security and Cultural Transformation in Samoa, Niue and New Zealand. Wydawnictwo Adam Marszałek.

Jaworowska, M. (2019). Socjologia bezpieczeństwa. Wybrane problemy. Toruń.

Jaworowska, M. (2020). Bezpieczeństwo socjalizacji pokoleniowej w aspekcie ciągłości tradycji wspólnoty kulturowej. In T. Zwęgliński (Ed.), Badania i edukacja $w$ kształtowaniu kompetencji specjalistów bezpieczeństwa wewnętrznego (pp. 17-51). Warszawa.

Jemioło, T., Dawidczyk, A. (2008). Wprowadzenie do metodologii badań bezpieczeństwa. Akademia Obrony Narodowej.

Marszałek-Kawa, J. (Ed.) (2011). Zagrożenia dla bezpieczeństwa międzynarodowego w XXI wieku. Azjatycka perspektywa. Wydawnictwo Adam Marszałek.

Mead, M. (1978). Kultura i tożsamość. Studium dystansu międzypokoleniowego. PWN.

Mead, M. (1986). Trzy studia. 1. Dojrzewanie na Samoa, 2. Dorastanie na Nowej Gwinei, 3. Płeć $i$ charakter $w$ trzech społeczeństwach pierwotnych. PIW.

Murdock, G.P. (1960). Cognatic forms of social organisation. In G.P. Murdock (Ed.), Social structure in Southeast Asia. New York Wenner-Gren Foundation.

Meleisea, M. (1987). The Making of Modern Samoa: Traditional Authority and Colonial Administration in the History of Western Samoa. Institute of Pacific Studies of the University of the South Pacific

Kruse-Vaai, E. (2011). Producing the Text of Culture. The Appropriation of English in Contemporary Samoa. National University of Samoa.

Smelser, N.J. (1968). Essays in sociological explanation. Englewood Cliffs.

Ścibiorek, Z., Zamiara, Z. (2016). Teoretyczne i metodologiczne podstawy problemów z zakresu bezpieczeństwa. Wydawnictwo Adam Marszałek.

Tiffany, S.W. (1980). Politics of land disputes in Western Samoa. Oceania, 50 (3), 176-208.

Turner, G. (1989). Samoa, A Hundred Years Ago and Long Before. University of the South Pacific.

William, J.H. (1996). Samoan Culture. Ati's Samoan Print Shop.

Weston, S.W. (1972). Samoan social organisation: structural implications of an ambilineal descent system. University of California. 